\title{
INQUIRY-BASED LEARNING EMBEDDED IN 5E LEARNING STRATEGY TO INVESTIGATE LEARNING PROGRESSION OF GRADE 9 STUDENTS FOR FORCE AND EFFECTS OF RESULTANT FORCES ACTING ON OBJECTS CONCEPTS
}

\author{
Prissana Rakbamrung ${ }^{1 *}$ and Kanokwan Thongked ${ }^{1}$
}

\author{
${ }^{1}$ General Science Education Program, Faculty of Education, Suratthani Rajabhat University, Thailand
}

\begin{abstract}
Force and effects of resultant forces acting on objects concepts are difficult or abstract for our students. Thus, the main goal of this article focuses on improving academic achievement and learning progression of students. The research was designed as quasi-experimental design. We used both quantitative and qualitative data in order to investigate students' achievement and learning progression. We developed 9 multiple choice items and 4 open-end question for pre-test and posttest. Our examination was designed to assess knowledge, comprehension and application skill. Inquiry-based learning embedded in $5 \mathrm{E}$ learning strategy had potential to evaluate students' prior knowledge, and develop prediction, observation and interpreting data, collaboration and communication skill. The results found that $64.29 \%$ of students understood completely about the concept of force and net force insert on the object. Only $35.71 \%$ of students partial understood and no student miss concept. Moreover, students showed their learning progression in the positive way. In this point of view, we suggest that inquiry-based learning embedded in $5 \mathrm{E}$ learning strategy should be extent to the other abstract contents related to force concept.
\end{abstract}

Keywords: force and net force insert on the object; inquiry; 5E learning strategy; learning progression.

\section{Introduction}

There are a number of models of inquiry in learning science. Inquiry-based learning has been widely promoted to increase literacy and skill development (Brickman et. al., 2009) critical thinking skills (Thaiposri and Wannapiroon, 2015) learning motivation and interest (Wang et. al., 2015). The 5E leaning strategy has been proven to be one of the most effective inquiry learning model for physics and others sciences (Lena Ballone Duran and Emilio Duran, 2004). These learning processes are best accomplished using more student-centered active-learning strategies. For instance, exploration, questioning, making discoveries, and testing discoveries to search for new understanding (Lemlech, 2009).

Force and effects of resultant forces acting on objects concepts are graps to understanding (Prissana Rakbamrung and Preeyanan Thepnuan, 2013. Prissana Rakbamrung, 2015). Most of research focus on students' concept or perceptions while rarely research discuss about learning progression (Philip Johnson, 2013). Moreover most research use inquiry based learning without integrating with other learning approaches. This work thus interested in integrated inquiry based learning with 5E learning to investigate learning progression. 


\section{Research goal and question}

The present study intended to investigate academic achievement and learning progression of students. Learning through integrating Inquiry with 5E learning activities in stoichiometry. This aim raised the following question: can and to what extent can integrating Inquiry with $5 \mathrm{E}$ learning activities in stoichiometry improving academic achievement and learning progression of students towards science learning?

\section{Methodology}

\section{Research design}

This study was conducted at a middle school located in the western Thailand. The samples were 28 grade 9 students enrolled in science course for the first semester in 2017. The mixed-method approach employed to develop and validate a learning progression and assessment for teaching force and net force insert on the object concepts. The twelve multiple choice questions and 4 open-end questions were constructed by the authors but only ten multiple choice questions were used as pre- and post-test as a result of index of item objective congruence (IOC) which were evaluated by three physics experts. The usefulness of pre- and post-tests were quantitative indicator to measure student learning outcomes: academic achievement and learning progression. These tests also were used to identify and assess the possible effectiveness of an inquiry-based approach to $5 \mathrm{E}$ learning strategy. During students participated in an inquiry activity, the authors also gathered qualitative data from their work sheets. The treatment tools combined a developed lesson plan and a phet simulation (from: https://phet.colorado.edu/th/simulation/forces-and-motion-basics) were implemented to introduce learning context and activities for 60 minutes.

\section{Learning context}

The professional competences of music teachers have also been studied by J. Abramauskienè (2002), M. J. Bergee \& S. M. Demorest (2003), J. Eros (2013), Koca (2017) and other scholars. The works of these authors mostly emphasize the teacher's subject competence, while other scholars (Isbell, 2008, Begić, et al., 2017) focus on the importance of the personalities of the teacher pedagogical, psychological qualities and socialization for the successful work of the music teacher. These are key factors in aiming to distinguish the competences of a contemporary music teacher.

\section{Organization of the Study}

\section{Research Instrument and Methodology}

Standard 4: Forces and Motion

Standard Sc4.1: Understanding of the nature of electromagnetic, gravitational and nuclear forces; investigative process of seeking knowledge and applying acquired knowledge for useful and ethical purposes

Grade level indicators for grade 9 student is explain acceleration and effects of resultant forces acting on objects. 


\section{Learning Procedure}

This action research based on the POE (prediction-observation-explanation) approach. It was a problem-based lesson, taking 60 minutes for a period. The 5E learning strategy in the present study composed of five leaning steps as following:

Step1: Engagement - students were engaged in simple questions for 10 minutes in order to assess their prior knowledge from a previous class and their experiences in daily life. For this step, instructor asked students to observe a table which located in front of a class and used the simple questions such as what was a table moving? and how did a table move when student pushed it? Moreover, students should know about the basic knowledge of force concept such as its definition, unit, quantity type, and the effect itself.

Step 2: Exploration -the instructor showed the students how to learn from simulation (Figure1) and brief a basic concept on force characteristic and the Newton's first law of motion. Then each group of students (3-5 students for each group) was self-studied by watch forces in action and to record as many forces as possible. This step students could predict, observe, and explain on what they found from learning tool which took time only about 15 minutes.

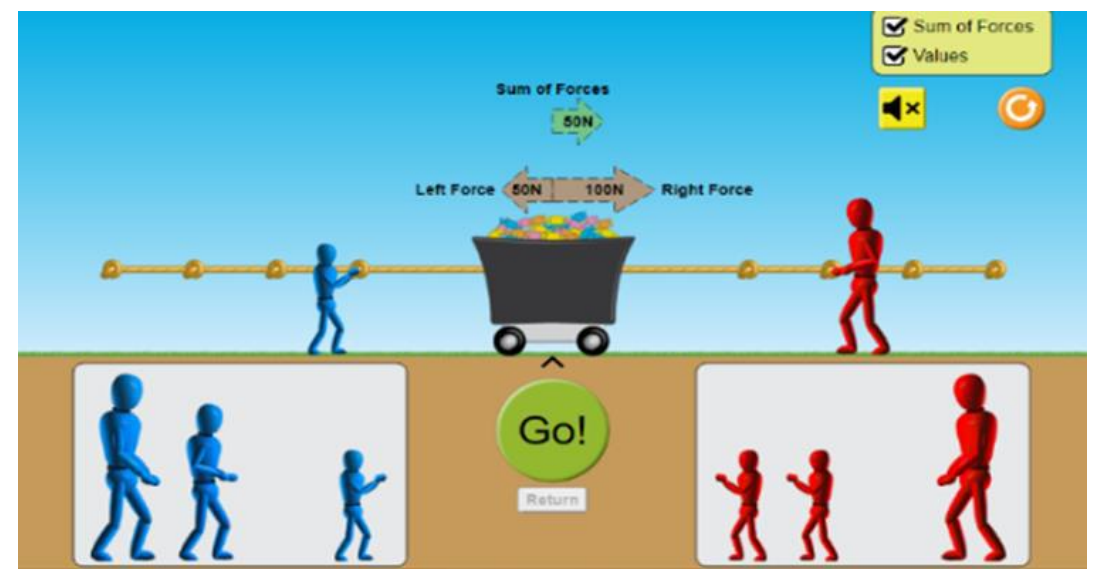

Figure 1 Show simulation about a basic concept on force characteristic and the Newton's first law of motion. (From: https://phet.colorado.edu/th /simulation/forces-and-motion-basics)

Step 3: Explanation - this step took one on fourth of a period, thus, the instructor chose only two questions to assess students' understanding and asked students to summarize on the Newton's first law of motion. As students could give knowledge gained by their comprehension, students in each group were asked to give an example of daily life phenomena and draw a concept map on their note books.

Step 4: Elaboration or Extension- students extend and applied their finding in a new context, especially a daily life one. Instructor asked them to divide into 4 group to lean through activity name "bomb disposal". Students in each group had to use force in equal for all fore for save them from a bottle bomb as shown in Figure2. 


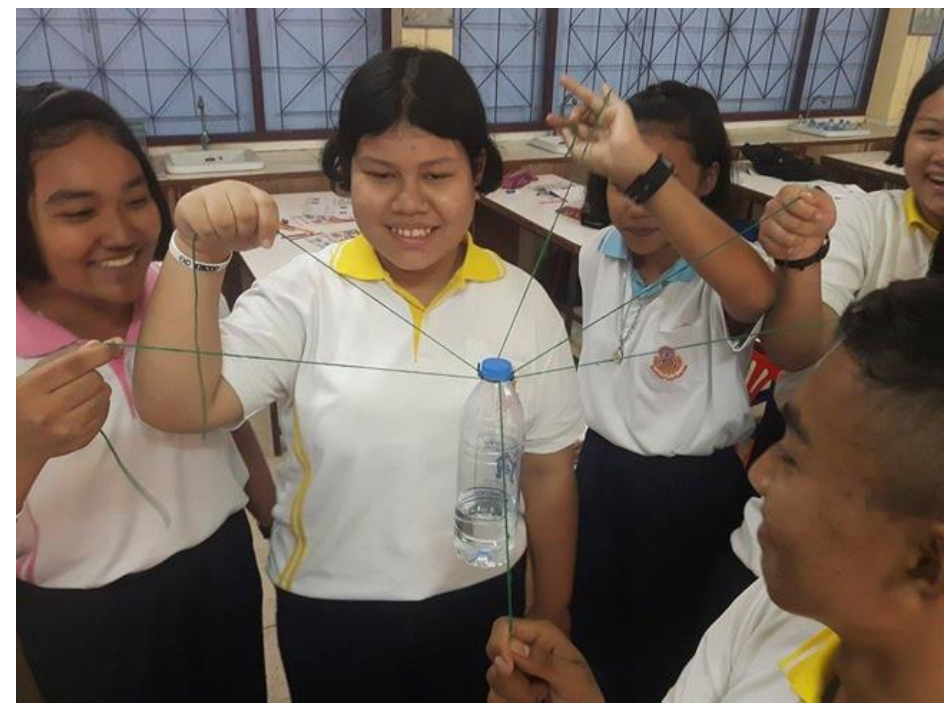

Figure 2 Show simulation about a basic concept on force characteristic and the Newton's first law of motion.

Step 5: Evaluation - students evaluated their experimental process and results in a variety of ways, such as an activity report, instructor observation during activity, and student presentations.

\section{Results and Discussion}

The results of this research are presented in the following sections.

\section{Academic achievement}

Table 1: Mean scores and standard deviations of the pre- and post-questions of 28 students

\begin{tabular}{llll|llll}
\hline Pre-test & & & & \multicolumn{3}{l}{ Post-test } \\
\hline $\mathrm{N}$ & $\mathrm{n}$ & Mean & S.D. & $\mathrm{N}$ & $\mathrm{n}$ & Mean & S.D. \\
\hline 28 & 0 & 5.43 & 1.52 & 28 & 27 & 10.68 & 1.20 \\
\hline
\end{tabular}

$\mathrm{n}=$ The number of students who gained higher than the prescribed criterion of $60 \%$. $\mathrm{N}=$ The number of sample.

Table 1 shows the average results of the pre-tests and the post-tests according to the achievement in the pre-test and the types of tasks. The criterion of $60 \%$ of the full score 13 points, which was 7.8 points, was used for passing the test.

\section{Learning Progression}

Figure drawing objective: Students created foreshortened figure drawing composition of bomb disposal activities with correct proportions and value gradation. 
Table 2: The students' drawing and correct proportions and value gradation.

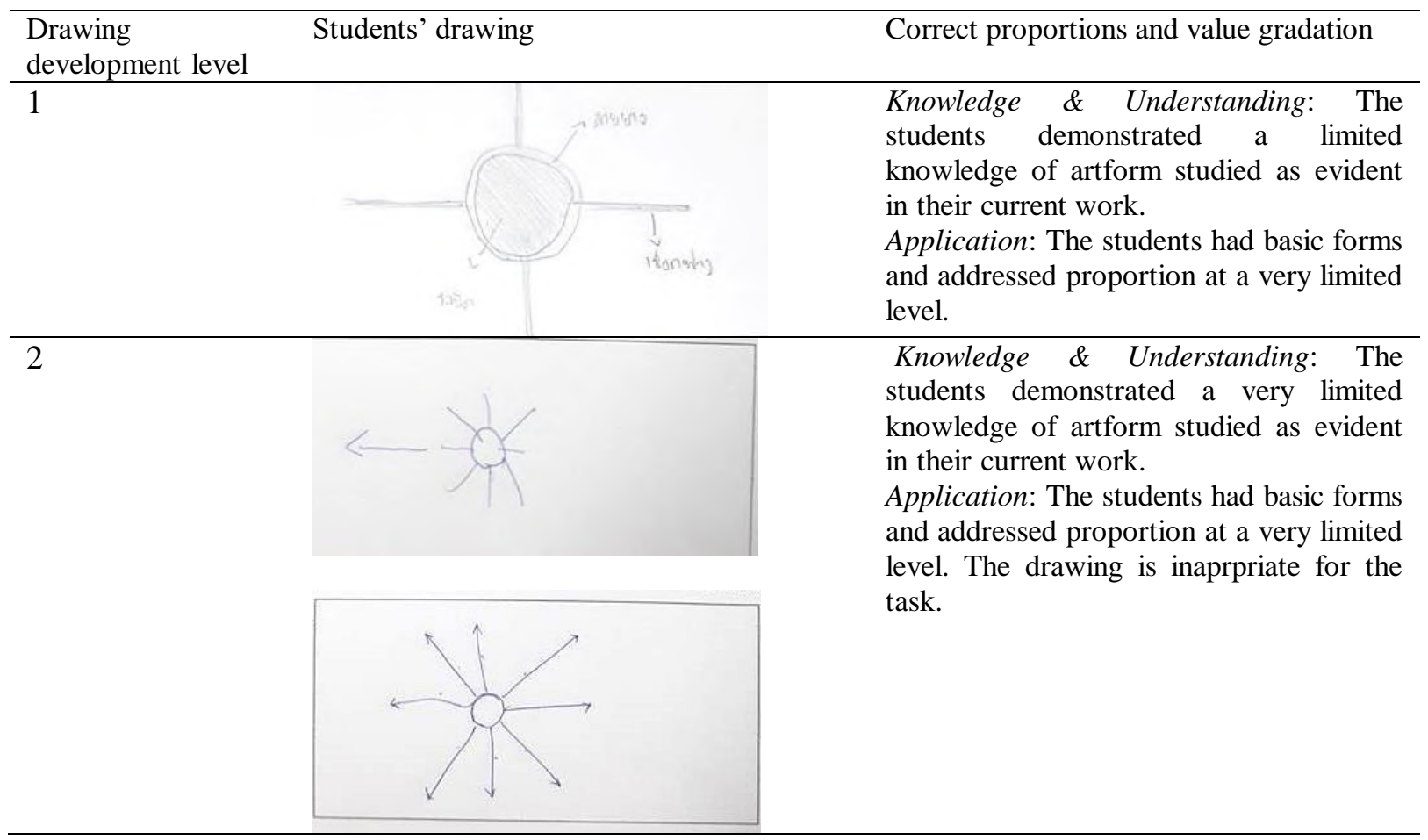

Table 3. Shows the students' drawing and descriptions of the free-body diagram representing the external forces acting on the bottle bomb and students' descriptions.

\begin{tabular}{ll|l}
\hline $\begin{array}{l}\text { Development } \\
\text { level }\end{array}$ & $\begin{array}{l}\text { Students' drawing of the free-body } \\
\text { diagram }\end{array}$ & $\begin{array}{l}\text { Students' descriptions } \\
\text { Rubber moved along direction of force. Force in each } \\
\text { direction is not equal. If force in left-hand direction } \\
\text { was higher than force in the right-hand direction, } \\
\text { bomb was occurred in left-hand direction. }\end{array}$ \\
\hline 2 & $\begin{array}{l}\text { Moving along force direction. Force is more than } \\
\text { zero then we can move the bottle bomb. }\end{array}$ & \\
\hline 3 & & \\
\hline
\end{tabular}




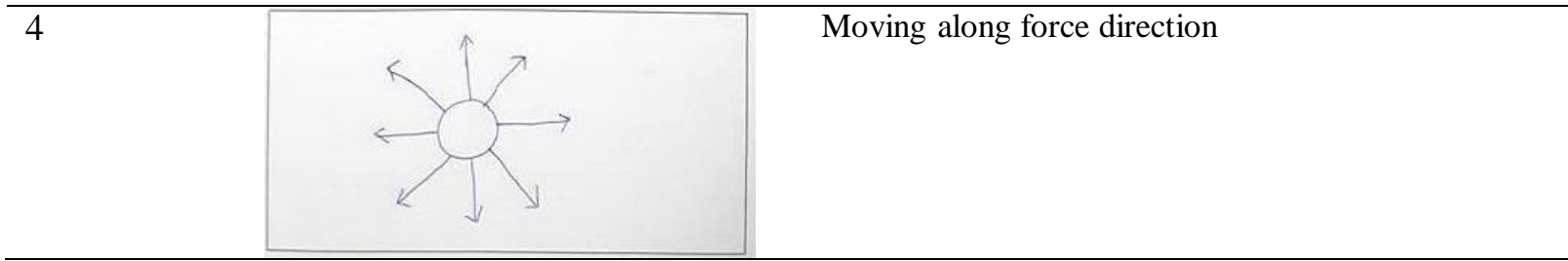

The students' drawing displays a basic drawing of free body diagram of a system which consist of an object and a various force vectors. The author can divide learning progression of student from theirs' drawing and description in to four stages as shown in Table 3.

\section{Conclusions and Suggestion}

This work can conclude that inquiry-based learning embedded in 5E Learning strategy in effective learning strategy as it can be in the form of problem and task for triggering student engagement. The experimental results indicated that students' learning progression for grade 9 students displayed knowledge, comprehension and application thinking skills. The positive in learning progression improve academic achievement for two times.

\section{Acknowledgements}

The authors would like to thank to Suratthani Rajabhat University for supporting.

\section{References}

Brickman P., Gormally C., Armstrong N., Hallar B., 2009, Effects of Inquiry-based Learning on Students' Science Literacy Skills and Confidence. International Journal for the Scholarship of Teaching and Learning, $3(2)$.

Lena B. D. and Emilio D., 2004, The 5E Instructional Model: A Learning Cycle Approach for Inquiry-Based Science Teaching. The Science Education Review, 3(2), 49-58.

Lemlech, J. K., 2009, Curriculum and Instructional Methods for Elementary and Middle School (7th Edition). (Upper Saddle River, New Jersey, Pearson.) In Suduc A.-M., Bizoi M. and Gorghiu G. Inquiry Based Science Learning in Primary Education. Procedia - Social and Behavioral Sciences, 205,474 - 479.

Philip J., 2013, A learning progression towards understanding chemical change. Educatión Quimíca. 24(4),365-372.

Prissana R., 2015, The usefulness of magnets for teaching gravitational acceleration. Physics Education. 50 (2), 137-141.

Prissana R., Preeyanan T., 2013, Impact of problem-based learning in learning force and motion through difference styles of students' demonstrator. Proceeding of international conference "New perspective in science education, Florence (Italy), pp.1-5.

Thaiposri P., Wannapiroon P., 2015, Enhancing students' critical thinking skills through teaching and learning by inquiry-based learning activities using social network and cloud computing. Procedia - Social and Behavioral Sciences, 174,2137-2144. 